\title{
Anderbereddering: Met Adorno by die hartslag van die postmoderne intellek
}

C Johann Beukes

Kriel

\begin{abstract}
Other illumination: With Adorno at the heartbeat of the postmodern intellect

In this article Adorno's critique of identity thinking and modern systems of thought are exploited within the context of the current debate of modernity. It is argued that the usurpation of the so-called Other (which the author calls "Anderverdringing") is at the core of modern thought, and that the illumination of the Other (which the author calls "Anderbereddering") is at the core of postmodern thought. Habermas' theory of communicative action is used to bring Adorno's critique of identity thinking to the fore as a form of postmodern critique, exactly in the sense that Adorno's philosophy is essentially Otherilluminating.
\end{abstract}

Das Ganze ist das Unwahre. (Theodor W Adorno)

\section{INLEIDING}

Die moderniteitsdebat, wat sisteemkritiek hoog op die agenda het, is kompleks. Gespreksgenote vind mekaar moeilik, veral binne die dissiplines wat vroeër (in moderniteit) ensiklopedies skerp van mekaar afgegrens is. Dit geld ook vir (moderne) teologie en (moderne) filosofie. Daarom sou dit bevorderlik vir die gesprek rondom postmoderniteit wees om bepaalde invalshoeke aan die orde te stel, in terme waarvan toeganklikheidsprobleme en konsensusprobleme oor wat die moderne problematiek behels, besweer kan word.

Hierdie artikel wil poog om so 'n invalshoek aan die orde te stel en sommige van die moderniteitsdebat se komplekse nuanses te verhelder deur 'n argumentatiewe weefdraad in hierdie debat uit te wys en die implikasie daarvan te beredeneer: dit behels

* Hierdie artikel is gebaseer op navorsingsresultate verkry in die DLitt et Phil-proefskrif van C J Beukes, 'Nietzsche in Adorno: Oorspronge van postmoderniteit?' Departement Filosofie, Randse Afrikaanse Universiteit 1995, onder leiding van prof dr J J Snyman. Publikasievergunning en finansiële bystand deur die Randse Afrikaanse Universiteit en die Sentrum vir Wetenskaplike Ontwikkeling word hiermee met dank erken. 
naamlik die postmoderne filosofie se sisteemkritiese tegemoetkoming of bereddering van die verdronge aspekte van die moderne werklikheid, wat Anderbereddering genoem kan word. Die gedagtekomplekse en redelikheidsvorme wat sistematies/sistematiserend deur die moderne diskoers verdring en onderwerp is, kan spesifiek in navolging van Derrida, só die 'Ander' (l'Autrui) genoem word (kyk bv Derrida se gesprek met Levinas [1978:102vv]).

Die vertrekpunt hier is dat die sentra van die moderne problematiek en postmoderne kritiek teruggevind kan word in wat 'Anderverdringing' en 'Anderbereddering' genoem kan word. Hierdie begrippe dui nie in die eerste plek die instrumentele redelikheidsvorm van moderniteit self aan nie, maar wys eerder op die nawerking van instrumentele redelikheid. Die begrippe 'Anderverdringing' en 'Anderbereddering' is dus gerig op die toestand wat deur moderniteit se instrumentaliserende onderwerping van die werklikheid meegebring is.

Indien hierdie twee diagnoserende begrippe en hul betekenis aanvaar word, word die moderniteitsdebat via hierdie invalshoek ineens 'n baie meer toeganklike debat. Dit moet egter duidelik gestel word dat hier op 'n spesifieke - en die belangrikste moment van postmoderniteit gefokus word, naamlik die postmoderne intellek: dit gaan dus hier oor redelikheid en die operatiewe stelreëls waarvolgens redelikheid - modern en postmodern - funksioneer en/of opgehou funksioneer het. Aanverwante kwessies, veral die soorte maatskappykritiek en estetikas wat uit hierdie redekritiek voortkom, word nie hier beredeneer nie.

Die argument word soos volg ingerig: (1) Agtergrondsgewys word Anderverdringing as ' $n$ wesenskenmerk van die moderne filosofie verduidelik. Dit kom kortliks daarop neer dat die moderne diskoers met treurige gevolge verdringend en onderwerpend met bepaalde segmente van die werklikheid omgegaan het. (2) Voorts word 'n wesenskenmerk van die postmoderne filosofie beskryf, naamlik dat die postmoderne filosofie poog om die moderne Anderverdringing en algemene onderwerping van die werklikheid hok te slaan, met tegemoetkomende gevolge vir hierdie Ander, die verdronge segmente van die werklikheid. Opvolgend word daar aan die hand van (3) Habermas en (4) veral Adorno se identiteitskritiese insigte aangetoon waarom dit noodsaaklik geword het dat ons die sisteemkritiese implikasies van postmoderniteit ernstig sal moet neem.

Die argument aspireer voorlopig nie om meer te wees as perspektiefverbredend nie: gevolglik is ' $n$ beter begrip van wat die problematiese konsep 'postmoderniteit' behels, 'n moontlikheid.

Hierna sal dit in postmodern-sisteemkritiese sin ook duideliker blyk dat teologie en filosofie wesenlik keerkante van dieselfde saak is, en dat dit nie net onnodig nie, maar in die postmoderne tyd - in sisteemkritiese sin — onmoontlik geword het om teologie en filosofie van mekaar te skei. Anders gesê: dat dit 'n 'filosofiese teologie' is, met 
Die gevolg van die werksaamhede van die rasionaliste, en daarna Kant en uiteindelik Hegel - ongeag die verandering met betrekking tot die bewuswording van die begrensdheid van die rede - is dat die rede pretendeer om die geheel te ken en niks (hoef) uit te sluit nie, maar dit desnieteenstaande wel doen. Dat hierdie paradoks vir beide Kant en Hegel bewustelik uiters problematies was en dat hulle in hulle filosofieë skuiwergate hiervoor probeer inbou het (by Kant die estetika en by Hegel die dialektiek), is nie nou ter sake nie: wat wel ter sake is, is dat die rede ook na Kant en Hegel weier om te kapituleer voor die dwang om erkenning te gee aan dié dinge wat nie in sy bloudruk pas nie. Die moderne rede is behep met presisie en metode, en verdring alles wat nie so presies en metodies is nie.

Die postmoderne filosofie trek die verset teen die suiwerheid en onbegrensdheid van die rede wat by Kant en Hegel begin het, na ekstreme eindes deur. Dit is die hartslag van die postmoderne intellek.

\section{ANDERBEREDDERING AS DIE FILOSOFIESE DISKOERS VAN POST- MODERNITEIT}

Die postmoderne filosofie neem haar vertrek in onder andere hierdie probleem van verdringing van dinge tot buite die sisteem. Dit dra daartoe by om van moderniteit self 'n probleem te maak. Moderniteit word 'n probleem genoem, omdat daar geen eenstemmigheid tussen eietydse, hoofstroom filosowe bestaan wat die werking van moderniteit behels nie, en daarom bestaan daar ook geen konsensus oor wat postmoderniteit is nie. Postmoderniteit kan egter op die minste verstaan word as die totaliteit van ons eietydse werklikheid en nie bloot 'n filosofiese en/of literatuurteoretiese tendens nie. Die postmoderne toestand is op die minste 'n totaliteit met 'n baie spesifieke gerigtheid. Postmoderniteit se aanspreke is dus nie algemeen nie. Postmoderniteit behels 'n besliste wantroue in die vermoë van die moderne (instrumentele) rede en wil 'n direkte teenspraak wees van moderniteit se pretensie van 'n selfgenoegsame rede. As teenspraak en teenhanger kleef daar iets subversiefs en selfs anargisties aan postmoderniteit: dit is radikaal teen-modern eerder as ultra-modern. Postmoderniteit is Anders as moderniteit, en het tewens uit hierdie Andersheid ontstaan. Postmoderniteit, veral by denkers soos Foucault, toon daarom ook dikwels 'n gewelddadige geneigdheid om moderniteit te konfronteer en van moderniteit afskeid te neem.

Daar sou baie breed en veralgemenend gestel kon word dat die postmoderne filosofie deur die moderne bewussynsfilosofiese pretensie, wat progressief vanaf veral Descartes na Hegel opgetree het, gebreek het. Die postmoderne filosofie begryp naamlik die belang van 'n onderskeid tussen ' $n$ verdringende (moderne) en 'n beredderende (postmoderne) rede: reeds voor die moderne rasionaliste soos Descartes, was die rede 
in die Griekse filosofie eksklusief. Die rede het uitgesluit, veral met betrekking tot die neiging om die dinge wat nie in sy kraam pas nie, in die ongelyk te stel deur dit as nietig of minstens 'minder werklik' te bestempel. Die Westerse rede was van meet af aan diskriminerend: die rede het gediskrimineer teen die veranderlike, die eindige, die toevallige, die partikuliere, die affektiewe en veral die irrasionele en a-rasionele. Die Westerse rede het in die proses die blywende, die oneindige, die noodwendige, die universele, die argumentatiewe, die onbetwyfelbare en uiteindelik by Hegel die onbetwisbaarheid van 'n rasioneel-kenbare Absolute Gees begunstig.

Die postmoderne filosofie het egter begin om die rede juis te definieer in terme van die uitsluitings wat hy maak: wat vir 'n filosofie of epog as redelik gegeld het, word volgens die postmoderne filosofie omgekeerd duidelik wanneer aangetoon kan word wat vir hom as onredelik, ontoelaatbaar en verdronge - dit wil sê as Anders - gegeld het.

Michel Foucault, byvoorbeeld, het in sy werk baie moeite gedoen om hierdie verdringingsprosedures te identifiseer wat volgens hom werksaam sou wees in die Westerse filosofiese diskoers vanaf die Grieke tot by die moderne filosowe, en het hierdie meganismes van uitbanning, verbanning en verdringing doelgerig aangespreek. Foucault se mees basiese argumentatiewe premisse was dat die moderne rede homself handhaaf deur verdringing en uitsluiting.

Martin Heidegger, wat Foucault grootliks voorafgegaan het, se stellingname was nie veel anders nie: die rede as wetenskaplike rede (wat ontspring vanuit metafisiese rasionaliteit) is eensydig afgestem op das Seiende, terwyl die Sonstige, die Gans Andere, uitgesluit word. Heidegger se filosofie kan verstaan word as onder andere 'n poging om hierdie Ander in die spel te bring, ten einde werklik te kan verstaan watter uitsluitingsaktiwiteite werksaam was sedert die Grieke tot by wat Habermas die bewussynsfilosofiese paradigma noem. Heidegger het gepoog om die geskiedenis van die Westerse ontologie sistematies en krities na te gaan, ten einde die hoë frekwensie van voorkeur aan sekere werklikhede en die verdringing van Ander werklikhede, aan te stip. Vir Heidegger, sou oorhoofs opgemerk kan word, was dit veral die eindigheidsdimensie van tyd, dat die mens Sein zum Tode is, wat só verdring is. Hierdie eindigheidsbesef word verdring ter wille van die beskouing dat die tyd 'n opeenhoping van teenswoordige momente is en die werklikheid gelykgestel word met dit wat bestendig teenwoordig is. Die metafisika en die wetenskap werk ook nie anders nie. Die aandag word toegespits op dit wat verskyn binne die dimensie van tyd, maar met die tydsdimensie self word nie rekening gehou nie. Ook hier, byvoorbeeld, bly die rede pretensieus-redelik deur verdringing. 
Die postmoderne filosofieë van onder andere Nietzsche, Heidegger, Foucault en Derrida wil rekening hou met hierdie basiese probleem van pre-moderniteit en moderniteit: die rede in die Westerse tradisie was altyd 'n eksklusiewe, Anderverdringende rede. Die postmoderne agenda word grotendeels in beslag geneem deur die vermoede dat die ware aard van die rede dáár lê waar hy nié verdring nie, en die poging om aan die bewussynsfilosofiese paradigma as die spitspunt van hierdie verdringende werksaamheid te ontkom. Uit die oeuvres van figure soos Habermas, Adorno, Foucault, Derrida, Levinas en Deleuze blyk dit as 'n kritiese vasstaande: Anderbereddering is die hartslag van die postmoderne intellek.

Vir die postmoderne filosofie, en Habermas het dit by uitstek sedert die vroeë tagtigerjare ingesien, tree die rede se ware aard na vore daar waar dit hom geluk om nié uit te sluit nie, maar die Ander te erken, te herken en in te sluit. Dit is ' $n$ betekenis wat Habermas wesenlik aan die begrip 'kommunikatiewe handeling' sou toeken.

Ware redelikheid sou vir die postmoderne filosofie dus 'n redelikheid wees wat bereid is om met die Ander in die reine te kom: nie daar waar sy die grense sluit en dele van die werklikheid verdring en uitban nie, maar daar waar sy die grense postmodern oopbuig en Ander werklikhede inlaat, en aan dit wat in die moderne bewussynsfilosofiese paradigma formeel nietig verklaar is, die nodige erkenning verleen. Hierdie (h)erkenning van die Ander beteken vir die postmoderne kritiek 'n regstreekse kritiek van die moderniteit/Verligting se aanvanklike verobjektivering en uiteindelike fragmentering van die werklikheid, want dit was by uitstek moderniteit wat in sy uitsluitingsmeganiese fragmentering van die werklikheid, aspekte van die werklikheid verdring en tot buite die ruimtes van die identiteit uitgeskuif het.

Postmoderne kritiek is daarom niks anders nie as 'n kritiek van die subjek wat vir hierdie fragmentering en verdringing verantwoordelik was en daardeur ten koste van die objektewerklikheid bevoordeel is. Die postmoderne kritiek is daarom nog meer spesifiek 'n skerp kritiek teen die outonome, rasionele en 'suiwer' Kantiaanse subjek. Daarom is dit ook ' $n$ kritiek teen enige eksakte en skerp onderskeiding, veral van subjek en objek. Postmoderne kritiek is by uitstek 'n kritiek wat die Ander invloede van die irrasionele op die rasionele, die pre- en nie-konseptuele op die konseptuele en die on(der)bewuste op die bewuste wil erken.

Postmoderniteit is egter nie bloot ' $n$ verweer ten gunste van irrasionalisme nie: dit gaan baie ruimer te werk. Postmoderniteit wil naamlik ook 'n verbreding van redelikheidsvorme teweegbring en alternatiewe vorme van redelikheid bekendstel en propageer. Waar modernisme redelikheid op instrumentele redelikheid gefikseer het, wil postmoderniteit dus alternatiewe of Ander vorme van redelikheid herwin (want postmoderniteit se punt is tog dat hierdie Ander nog altyd dáár was, maar verdring en uitgeban is deur instrumentele redelikheid). 
Postmoderne kritiek is in beginsel nie anders as dít wat Adorno die identiteitsdenke genoem het nie, want dit is immers die identifiserende subjek wat só uitsluitend identifiseer. Postmoderne kritiek is daarom ook gerig teen die dialektiek, juis omdat die Hegeliaanse dialektiek - wat die laaste gangbare bewussynsfilosofiese model van moderniteit was - 'n geslote dialektiek is wat bestaan by grasie van identifiserende en begripsmatige denke, en as geslote die Ander/nie-identiteit nie tot spreke kán bring nie. As sodanig bly die postmoderne kritiek teen wil en dank ook 'n kritiese gesprek met Hegel. Postmoderne kritiek is daarom 'n uiters selfkritiese en selfverwysende bedryf. Dit wil dan veral só opgaan as verruimende kritiek, akkommoderend skonoklasties, de(kon)struktief, oop. Postmoderne kritiek is 'n bereddering en redding van die Ander, dit wil sê die dinge wat deur die moderne filosofie uitgesluit en agtergelaat is. Postmoderne kritiek is daarom kritiek wat van die punt uitgaan dat moderniteit se atomisering of minstens dualisering van die werklikheid nie alleen opgehef moet word nie, maar ook introspektief en remediërend geheel kan word. Postmoderne kritiek is daarom by uitstek reddende kritiek: dit wil die gemarginaliseerde, die nie-identiese (Adorno se begrip) tegemoetkom en red. Dit wil dus rekening hou met die Ander. As dit so is dat moderniteit subjekpropagerend, selflegitimerend, geslote, uitsluitend en letterlik vernietigend met die werklikheid van die Ander omgegaan het, wil dit wat postmoderniteit genoem word, die teenoorgestelde doen.

\section{JÜRGEN HABERMAS: DIALOOG AS ANDERBEREDDERING}

Voordat Adorno 'n Anderberedderende spreekbeurt gegun word, sou dit 'n goeie strategie wees om eers sy destydse assistent en (nou beroemde) kollega, Jürgen Habermas, aan die woord te laat kom.

Habermas is gewis een van die belangrikste filosowe op die eietydse intellektuele toneel. Habermas (1987a) het, spesifiek in sy epogmakende teks, Der philosophische Diskurs der Moderne (The philosophical discourse of modernity), die eerste Duitse denker geword om Adorno tot sy reg te laat kom in die moderniteitskritiese gesprek. Hierdie teks het die filosofiese navorsingskring se verstaan van moderniteit in die algemeen asook lesings van sogenaamd modernistiese- en sogenaamd Marxistiese denkers, soos Adorno in die besonder, ingrypend verander. Habermas hanteer Adorno in hierdie bepaalde teks simpatiek en waarderend, ten spyte van ander baie skerp verskille tussen die twee denkers. Die rede vir hierdie (ietwat onverwagse) simpatieke hantering van Adorno, is dat Habermas ingesien het dat Adorno, parallel met uitgesproke postmoderniste soos Foucault, 'n sensitiewe aanvoeling vir die moderne meganismes van eindelose onderdrukking en beheersing geopenbaar het, terwyl beide Foucault en Adorno ook die Verligting se aanspraak op bevryding en vooruitgang deur 
redelikheid, doelgerig ondermyn het. Habermas se (nou reeds bekende) betoog vir intersubjektiwiteit is niks anders nie as ' $n$ baie tydige en waarskynlik geslaagde poging om die Self - ofte wel dit wat Adorno die subjek van die identiteitsfilosofie genoem het - en die Ander - ofte wel dit wat Adorno die nie-identiese genoem het - met mekaar in gesprek te bring, sonder om van voor af in die Anderverdringende paradigma van filosofieë van 'n suiwer bewussyn te verval. Habermas se filosofiese doel is om 'n soort intersubjektiewe redelikheid wat as kommunikatief-handelend verstaan behoort te word, uit te werk en daar te stel. Dit is sy antwoord op die filosofiese probleem van moderniteit. Die kritiek van die rede is vir Habermas noodwendig terselfdertyd kritiek van die rasionele subjek en daarmee saam 'n kritiek van die Self. Teenoor (en dikwels ook buite) die Self staan alles wat anders as die Self is: die Ander. Onderliggend aan die kritiek van die subjek is daarom die vraag na die Ander, soos vergestalt in die huidige (postmoderne) stemme wat by uitnemendheid daarin ge slaag het om die aansprake en invloede van die irrasionele en a-rasionele op die sogenaamde rasionele, die pre-konseptuele en nie-konseptuele op die konseptuele eietyds te verklank. Strukture en kategorieë waarmee die Ander geken kan word, moet volgens Habermas egter steeds as intrinsiek maatskaplik gereken word, terwyl denkkategorieë wat die Ander uitsluit - soos die instrumentele rede - nie (langer) ongekwalifiseerd houdbaar in terme van afgegrensde begrippe soos geskiedenis, tradisie en kultuur is nie. Om die Ander te laat praat, moes geskiedenis, tradisie en kultuur vloeibaar gemaak word. Hierdie vloeibaarheid stig volgens Habermas aversies ten opsigte van alles wat nie vloeibaar is nie: dit geld veral 'n aversie met betrekking tot teenoorplasings, omdat sodanige teenoorplasings die Self en die Ander eg-modern en eg-bewussynsfilosofies bly opponeer. Daarmee saam ook 'n aversie ten opsigte van gees teenóór lyf, poësie teenóór wetenskap en geloof teenóór ongeloof. Die uitdaging is vir Habermas daarin gesetel om nie oorhaastig en oorboord te gaan met postmoderne verdagings van die subjek nie. Die uitdaging is volgens Habermas eerder geleë in die oordenking van die rede in terme van die rede se begrensdheid. Anders gesê, om met inagneming van die historiese en maatskaplike ingebedheid van die kennende en handelende subjek (nogtans) te bly reflekteer. Die belangrike kode by die ontsluiting van Habermas se tekste is dus sy verwerping van 'n bewussynsfilosofiese paradigma en die daarmee-geassosieerde filosofie van die subjek (wat 'n selfgenoegsame en verdringende subjek is wat niks anders as die verdringing van die Ander impliseer nie). Hierdie tipe paradigma word deur hom vervang met die intersubjektiewe paradigma van die kommunikatiewe handeling: die Self en die Ander kom in gesprek en bly altyd in gesprek. Met hierdie intersubjektiewe program het Habermas self 'n waarskynlik-geslaagde platform geskep vir die redding/bereddering van die Ander: want dit is daar waar Self en Ander met mekaar in gesprek kom, dat die Self behoue bly. In hierdie Anderberedderende opsig is Habermas se argumente postmodern-gevolgryk, al sou hy hom ook ver- 
set teen die postmoderne etiket. In die werk van Habermas tref ons dus 'n uitnemende voorbeeld van die hartslag van die postmoderne intellek aan: Anderbereddering as die filosofiese diskoers van postmoderniteit.

Habermas se argument kan geresumeer word in sy opvatting dat die kognitiewe en instrumentele verhouding tussen subjek en objek, en dié se gepaardgaande rasionaliteitsvorm wat die sentrale vooronderstelling van moderne filosofie was (is), beskou moet word as ingebed in ' $n$ breër kommunikatiewe rede. Hierdie breër kommunikatiewe rede is inherent aan die intersubjektiwiteit van dialoog en waaraan subjekte moet konformeer ten einde wedersydse begrip en verstaan te verwesenlik. Volgens Habermas kan die instrumentele rede nie pragmaties gereduseer word tot 'n element of moment in die siklus van die subjek se selfhandhawing nie, maar voorbehou eerder aansprake op die waarde van kennis en handelinge. Hierdie kognitiewe en handelingsaansprake kan uiteindelik slegs getoets en besleg word deur intersubjektiewe debatvoering (Habermas 1984:10vv). Hierdie argument kom neer op'n verskuiwing vanaf 'n bewussynsgesentreerde filosofie na 'n kommunikatief verbredende filosofie van taal. Dit stel hom in staat om te betoog dat daar ander vorme van rasionaliteit bestaan as net die rasionaliteitsvorm wat die kognitiewe en instrumentele verhouding tussen die subjek en objek dikteer. Hierdie tipe rasionaliteit staan dus spesifiek in verhouding tot die kognitiewe dimensie van taal wat manifesteer in spraakhandelinge. Elke sodanige spraakhandeling beskik oor ' $n$ interaktiewe en artikulerende dimensie: hierdie dimensie vestig 'n verhouding tussen pratende subjekte en vergestalt die motiewe en bedoelinge van sodanige pratende subjekte. Volgens Habermas word hierdie unieke modi van kommunikasie ook belig in regulerende en verteenwoordigende spraakhandelinge, en dít vorm die grondslae van die rasionaliteitstipes wat Habermas die 'moreel-praktiese' en die 'esteties-praktiese' noem.

Hierdie dialoog-stigtende argument van Habermas is dus by uitstek Anderberedderend, en het ook waarskynlik die mees algemene voorbeeld geword van die Anderberedderende opgaaf van postmoderniteit.

\section{ADORNO: IDENTITEITSKRITIEK AS ANDERBEREDDERING}

Adorno se filosofie, naas die werk van die eietydse Franse en latere kollegas in Frankfurt (soos Habermas), kan as 'n doelgerigte poging om die nie-identiese/Ander te (h)erken, verstaan word. Dit plaas hom daarom binne die werksruimte van die postmoderne filosofie. Adorno se kritiek van die identiteitsdenke en sy reddende tegemoetkoming van die nie-identiese/Ander, is in hierdie modern-kritiese of postmoderne gespreksverband dus waardevol en betekenisvol. Dit is veral só postmodern betekenisvol in die sin dat dit ' $n$ houvas probeer kry op die vervreemdings- en veral verdinglikingsgevolge van die kontemporêre, tegnologies-Westerse beskawing. Die slagoffers van 
hierdie akute vervreemding is wat Adorno die nie-identiese noem. Adorno se kultuurkritiese program van die redding van die Ander, sowel as sy oorstyging van reglynigonderskeide en ensiklopediese geesteswetenskaplike grense, verbeeld sy waardering van die moontlikheid dat filosofie sélf 'n konstruktiewe visie op die menslike toestand aan die einde van moderniteit kan verskaf.

Adorno se filosofie behels ondere andere 'n skerp refleksie oor die stand van die gemarginaliseerde, die verdronge, dít wat hy in sy kritiek van die moderne identiteitsfilosofie die 'nie-identiese' genoem het. Adorno het dit nie oor filosofie nie. Hy het dit juis oor die dinge wat nooit as filosofie gereken is nie. Waar Marxisme, byvoorbeeld, oor sake soos 'utopie' definitiewe en vasstaande gedagtes gekoester het (in die onafwendbare aard van 'n reddende progressie in 'n dialektiese materialisme), was Adorno versigtig om oor enige utopie - daar waar die Ander tot hulle reg kom kláár te probeer praat. Met hierdie gereserveerdheid gee Adorno byvoorbaat uitdrukking aan een van die belangrikste en mees onderskatte karaktertrekke van sy filosofie: deur hom nie van 'n metodiese, suiwer-Marxistiese en daarom modernistiese sisteemdenke te bedien nie, slaag hy daarin om die bewussyn van die nie-identiteit of Ander nie verder te verdring nie, en slaag hy tewens daarin om die 'onartikuleerbare te artikuleer', die 'onsêbare te sê', en volgens eie opdrag dié opgaaf van die filosofie gestand te doen (Adorno 1973:25vv). Daar is reeds vermeld hoe die modernistiese bloudrukdenke dít wat Anders is, onderdruk het. Adorno se filosofie is onder andere daarop uit om hierdie Ander te rehabiliteer.

In Adorno, as 'n (Joodse) filosoof van die Ander, het 'n mens met 'n kulturele skeptikus te doen wat, as gevolg van dit wat hy van die Duitse Fascisme ervaar het, sterk regressief funksioneer. Die ervaring van Fascisme het by hom ' $n$ baie sterk kultuurskepsis agtergelaat. Hierdie skepsis vind byvoorbeeld neerslag in antikapitalisme en die radikale en meer dikwels uitsiglose kritiek van 'n massa- en verbruikerskultuur, wat, sover dit Adorno aangaan, gepaard gaan met sisteemdwang. Adorno staan skepties teenoor die gedagte van vooruitgang en die tegnologie se aanspraak op die verryking van die werklikheid. Hierdie gereserveerdheid ten opsigte van die moderne kultuur word deur ' $n$ diepe en swart pessimisme gedring, met slegs 'n baie skraal en problematiese verwagting van 'n oplossing en utopie. Sy ongekompromiteerde skepsis jeens die moderne kultuur en uitwasse van die moderne identiteitsdenke, soos in Fascisme, plaas Adorno op die baan van die Ander. Die feit dat Adorno van Joodse herkoms was, moet in hierdie verband nie onderskat word nie, alhoewel hy geensins op so 'n sterk wyse met Joodse tradisies geïdentifiseer het soos Derrida nie. Gebeure soos Auschwitz het nogtans 'n bepalende indruk op Adorno gemaak. In 'n sekere sin was sy Joodsheid vir hom die konkrete herinnering aan die nie-identiteit of Ander. Dit is so 
dat Adorno se anti-identiteitsfilosofie hom daarvan weerhou het om volledig in die Joodse tradisie op te gaan. Nogtans het Adorno die ervaring aan antisemitisme in NaziDuitsland digby meegemaak, en het dit sy beskouing van die Ander wesenlik beïnvloed. Dit vind byvoorbeeld weerklank in sy nou bekende uitspraak: 'Enige poësie na Auschwitz is barbaars' (Adorno 1977a:30). Sy Joodsheid was vir Adorno die realiteit van die nie-identiteit.

Adorno identifiseer lewe as nie-identiteit, of dit wat hier andersins tot dusver die Ander genoem is. Wat beteken nie-identiteit of Ander? Nie-identiteit is dít wat buite, eerder totaal Anderkant, die parameters van die moderne identiteitsdenke en identiteitswerklikheid lê.

Ons dink in identiteite: dit wat ons in staat stel om na-denkend te artikuleer. Adorno se kritiek van die identiteitsfilosofie kom daarop neer dat 'om te dink, is om te identifiseer en te onderwerp'. Wanneer ons menings vorm, vorm ons ons menings op die bekende, die goed wat name het. Die identiteitsdenke is imperialisties: dit wil enige iets Anderkant die grense van identifiserende kategorieë binnehaal in die grense van die begrip en dit onder die heerskappy van die identiteit inbring. Dit kan dít wat anders as die identiteitsbegrip is, in sy/haar Andersheid nie duld nie. Die identiteitsdenke staan sulke Andersheid dus teen en maak of dit nie bestaan nie of beveg die Ander onverbiddelik, om Adorno se konsekwente begrip, instrumenteel, te gebruik. Die nie-identiteit dui, om dit baie eenvoudig te sê, die versaakte werklikheid aan, 'n werklikheid wat nie mag bestaan nie, omdat die identiteitswerklikheid sê dat dit nie bestaan nie. Die identiteitsdenke se sogenaamde logika bring 'n basiese kenmerk van die moderne filosofie tot uitdrukking, naamlik die manier om dinge saam te dink en saam te bring, en dinge (reduserend) tot 'n eenheid te dwing.

Redelikheid behels volgens die identiteitsdenke om die universele of algemene tussen dinge te vind wat hulle 'logies' bind: ' $n$ wet, 'n essensie, 'n formule of beginsel wat bepaalde partikulieres as of binne of buite 'n bepaalde kategorie bring; iets wat dus hierdie partikulieres in terme van die een of ander (meetbare, substansiële) oorweging bymekaar dwing. Dit het nou reeds duidelik geblyk dat hierdie begripsmatige benadering ook die ervaring volgens ' $n$ eie agenda orden en in die proses totaliserende sisteme konstrueer waarvolgens die bepaalde kategorieë self weer gekategoriseer word tot 'n enkele beginsel wat die Geheel (Das Ganze) genoem kan word. Hierdie werking van die identiteitsdenke onderdruk dan die verskille wat partikulieres wel met mekaar binne die Geheel hou: Anderverdringend. Maar wat beteken nie-identiteit konkreet? 'Konkreet' beteken dat daar sake, begrippe en toestande is wat nie-identies is en wat met ander woorde - as aan die Anderkant - nooit tot spreke kom nie. 'n Jood in Duitsland in die vroeë jare 1930 verteenwoordig die konkrete belewenis van nie-identiteit. 
'n Intellektueel in die voormalige USSR is konkrete nie-identiteit. Native Americans is konkrete nie-identiteit. Swartmense in Suid-Afrika was sedert die dae van kolonialisering konkrete nie-identiteit. Vroue in ons samelewing is steeds konkrete nieidentiteit. 'n Protestant in Dublin is konkrete nie-identiteit. Met ander woorde, die begrip van 'lewe as nie-identiteit' en Adorno se intree vir en tegemoetkoming van die nie-identiteit, is nie ' $n$ afstandelike, vae en abstrakte indruk of gewaarwording nie: die nie-identiteit is toestand. Dit is daar. Dit artikuleer die onartikuleerbare, die gemarginaliseerde en verdronge toestande, wat toestande is wat self nie meer kan praat, dink of artikuleer nie. Dit is nie on-identies nie, maar nie-identies. Adorno se argumente wil op hierdie koers voortgaan: die moderne identiteitsdenke het nie, vanweë bogenoemde instrumentele rede wat doelmatig gedring word deur die identiteitsdenke, ooit met die nie-identiteitswerklikheid rekening gehou nie. Daar is nou reeds aangetoon dat die postmoderne filosofie, en Adorno het dit sterk geantisipeer, wel deeglik met die nieidentiteitswerklikheid van Andersheid rekening hou.

Ons lees soms dat postmoderniteit die 'ontslag van waarheid' beteken. Dit is nie waar nie. Postmoderniteit het dit oor 'n sekere soort waarheid, naamlik die instrumentele waarheid van die moderne Idealisme, en wil daardie totalitêre soort waarheidsaansprake verdaag. Vir Adorno as filosoof van die Ander gaan dit ook oor die aanvegting van 'n oorgeërfde waarheidsbeskouing en redelikheidsperspektief wat 'n mens in die kritiek van moderniteit totalitêr kan noem. Waarheid word naamlik idealisties slegs as sodanig beskou, solank as wat dit aan die vooropgestelde kriteria vir waarheid voldoen: dit moet byvoorbeeld onveranderlik wees (gefikseerd en staties), dit moet op 'n plek wees (binne die sisteem), en dit moet binne die sisteem verder verdeel en gekategoriseer kan word in byvoorbeeld fisiese teenóór metafisiese waarheid. 'n Verdere voorwaarde vir hierdie waarheid was dat dit 'n naam of identiteit moes hê: religieus byvoorbeeld 'God'; moreel byvoorbeeld 'Dít is goed en dít is boos, of sleg'; rasioneel, byvoorbeeld die Cartesiaanse cogito ergo sum, omdat ek dit dink - of omdat dit redelik is - is dit waar. Adorno se erfenis van waarheid is dat waarheid volledig gelyk aan identiteit is en slégs deur die identifiserende, uitsluitende aard van instrumentele rasionaliteit omvat kon word. Hy trek te velde teen hierdie moderne en idealistiese erfenis.

Adorno wil waarheid nie bloot epistemologies sien nie, maar as iets sosiaals. Met ander woorde, vir Adorno is waarheid iets wat in die samelewing te voorskyn tree. Die mens is daarom volgens hom tot in sy diepste wese gesosialiseer. Adorno is in sy samelewingsbeskouing ' $n$ funksionalis. Daarmee word bedoel dat hy van die gedagte uitgaan dat die samelewing iets is wat sigself deur, maar wesenlik agter, individue voltrek. Mense is in der waarheid onbewus van die samelewing, en die taak van die 
samelewingskritiek of sosiale filosofie in kritiese gedaante is om hierdie samehang tussen individu en samelewing (wat verborge is en verdring/onbewus gehou word deur die totale funksionaliteit en profytlikheid van die heersende struktuur) bloot te lê (kyk bv Adorno 1972:9-10). Hierdie siniese samelewingsbeskouing het veral te doen met die Ander wat nie pas nie en nie in-pas nie: ter wille van die ongelykes in die samelewing moet ons dus sinies wees.

Die kritiek van identiteitsdenke is Adorno se Anderbereddering. Hierdie venynige sisteemkritiek is in 'n laat Adorno-teks, naamlik Negative Dialektik, die bepalende gedagtegang. Die kritiek op die identiteitsdenke noodsaak 'n poging tot die bereddering en tegemoetkoming van die Ander; dit wat Adorno se filosofie eintlik wou doen en wat die rasionaal agter ' $n$ baie groot deel van sy filosofie was.

By Adorno, en dit moet gesoek word tussen die lyne in Negative Dialektik, sou 'n mens drie denkmodi kon onderskei. Die eerste modus is identiteitsdenke wat as pragmaties bestempel kan word en wat uitloop op die (misplaasde) verhouding tussen die universele (bo) en die partikuliere. Om Nietzsche se bekende voorbeeld te gebruik: die begrip 'blaar' pretendeer om universeel verteenwoordigend van alle blare te wees, al verskil verskillende soorte blare en ook blare van dieselfde soort. Identiteitsdenke is pragmaties in die sin dat dit vir ons dit maklik wil maak om oor blare te praat, al is dit dan ook ten koste van die uniekheid van elke blaar. Dit geld ook vir blare van dieselfde soort wat dieselfde lyk, maar nie dieselfde is nie. Deur van 'blaar' te praat, word die partikulariteit van elke, afsonderlike blaar oor die hoof gesien.

Adorno spreek hierdie verdronge partikulariteit, waarna hy as nie-identiteit verwys, aan vanuit ' $\mathrm{n}$ tweede modus, dit wat hy soms rationale Identität (bv Adorno 1973:148vv) noem. Hiervolgens wil Adorno spesifiek die valsheid van bogenoemde pragmatiese modus blootlê. Blare is nié gelyk aan 'blaar' nie. Die begrip 'blaar' reflekteer byvoorbaat utopies oor die blaar, asof die wesenlike of beste eienskappe van elke blaar in die begrip 'blaar' opgeneem is en dus asof die begrip wel die unieke aan elke blaar ondervang, wat vals is (Adorno 1973:148). Die begrip onderwerp juis partikulariteit en uniekheid. Die begrip stel nie die saak soos wat dit is nie. Tewens, dit stel die saak soos wat dit nié is nie.

Negatiewe dialektiek - as die kritiese bereddering van die Ander - sien hierdie onwaarheid in, verstaan dit en wil nooit daarin opgeneem word nie. Negatiewe dialektiek, as 'n soort derde denkmodus, sien in dat die begrip die saak nie wérklik identifiseer nie, omdat partikulariteit ondermyn en onderwerp is. Die oordeel 'vry man' (Adorno 1973:153) verwys byvoorbeeld na die begrip vryheid en nie na die saak - die spesifieke man - nie. Negatiewe dialektiek bevraagteken dus die verhouding tussen 
werklike werklikheid en begriplike werklikheid of konseptuele werklikheid. Negatiewe dialektiek wil dit wat agtergelaat is, probeer identifiseer deur die identifiserende handeling te negeer. Adorno self verwoord dit só: 'Die verstaan van nie-identiteit is daarin geleë dat dit identifiseer, selfs tot 'n groter mate, maar anders as identiteitsdenke. Hierdie verstaan van die nie-identiese wil 'n saak stel soos dit is, terwyl identiteitsdenke wil stel wat daaronder resorteer, waarvan dit ' $n$ afleiding of verteenwoordigend van is, wat dit juis nie is nie' (Adorno 1973:152). Identiteitsdenke maak dus ongelykes gelyk, en gelykes ongelyk (Adorno 1972:302, 347; 1973:146-151). Die negatiewe dialektiek wil hierdie leuenagtigheid van die identiteitsdenke blootlê en dit wat deur die begrip minstens agtergelaat is, reddend tegemoetkom. Hierdie reddende poging van die kritiek van die identiteitsdenke ten opsigte, en ter wille van die Ander, is dus die opgaaf van die negatiewe dialektiek. 'n Belangrike punt om te onthou is dat Adorno die kritiek van identiteitsdenke ter wille van die Ander inrig. Dit is nie kritiek ter wille van kritiek nie. Dit is 'n doelmatige kritiek en bly 'n kritiek van die rede. Dit is ook 'n negatiewe selfhandhawing van die kritiek van die rede.

'n Veronderstelling by die lees van 'n werk soos Negative Dialektik, waar Adorno die saak van die Ander op 'n spits dryf, is dat Adorno die samelewing nie net oorwegend nie, maar uit en uit negatief waardeer (Adorno 1973:41, 354). Daar is volgens Adorno in hierdie totaal negatiewe maatskappy geen moontlikheid om deur byvoorbeeld politieke handeling enige toestand van bevryding en versoening, wat as die mees algemene doel van die voorgeskiedenis gegeld het, te bereik nie. Die enigste oorblewe moontlikheid om nie volledig opgeneem te word in hierdie verduisterende negatiwiteit nie, is (tipies krities-teoreties) om nog met die saak van teorie te bly rekening hou. Die vraag kom egter dadelik by ' $n$ mens op: is dit enigsins moontlik om in die teorie nog ' $n$ vrye terrein vir refleksie, 'n ivoortoring te vind? Want dat teorie tot in sy 'inwendige samestelling' en in sy 'immanente waarheid' (Adorno 1973:16) afhang van die maatskaplike totaliteit, staan vir Adorno yas. Selfs die mees radikale kritiek kan nie 'n plek buíte die verdringende en onderdrukkende totaliteit inneem nie (kyk ook Adorno 1972: 369). Gevolglik wonder 'n mens of die teorie, ondanks die kritiese gerigtheid daarvan, nie aan alle objekte uiteindelik maar dieselfde onderdrukking toeken as wat die maatskaplike totaliteit in elk geval kenmerk nie? As Adorno se argument opgaan, naamlik dat alles en daarom ook teorie bepaal word deur totale onderdrukking, dan kan die teorie tog sekerlik nie anders nie as om sélf weer die onderdrukking uit te oefen? Hierdie vraag sny by 'n tema aan wat in Negative Dialektik werklik sentraal funksioneer: is dit hoegenaamd moontlik om 'n filosofie te ontwikkel waarin die dinge wat nog nie deur die onderdrukking opgeneem is nie, met ander woorde nog nie geïdentifiseer is nie, só begryp word dat dit nie gelyk te stel is of aaneengeskakel is met daardie filosofie/identiteit nie? 
In die beantwoording van sulke vrae sou Adorno die totale mensegeskiedenis, soos wat dit opgeneem is in die (Idealisme se) geskiedenis van denke, krities wou aanspreek. 'Die geskiedenis van denke is, sover as wat dit naspeurbaar is, 'n dialektiek van die Verligting' (Adorno 1973:124). Hier tree die postmoderne kwaliteit van die Adorniese kritiek van die identiteitsdenke op die voorgrond, en dit kan ook breed teruggevind word in Adorno se aanval op die subjeksentrisme en geheelgeoriënteerdheid van die Idealisme. Adorno kritiseer die Idealisme se transendentale bewussyn wat 'n eenheid tussen werklike werklikheid en begriplike werklikheid bewerk het, terwyl Adorno daarvan oortuig is dat daar ' $n$ onherroeplike breuk tussen begriplike werklikheid en werklike werklikheid bestaan. Adorno is bewus daarvan dat die oortuiging van hierdie breuk tussen begriplike werklikheid en werklike werklikheid blootgestel is aan die kritiek dat dit sélf op 'n begripsmatige onderskeid berus. Sy antwoord op sodanige kritiek sou egter wees dat sulke kritiek juis die illusie aan die Idealisme se eenheidsbeskouing beklemtoon, naamlik dat die moment van die nie-identiese in denke en ervaring gereduseer kan word tot 'n sisteem van begriplike bepalings en oortuigings. Adorno sê self: 'Filosofie het 'n deug gemaak van die probleem dat wanneer dit geldigheid aan die ervaring wil verleen, dit slegs oor 'n begrip van die ervaring beskik en nie oor ervaring self nie, en hiervan aflei dat ervaring ... self 'n begrip is' (Adorno 1974:286). Hierdie idealistiese illusie is volgens Adorno gegrond in die funksie van begriplike denke as iets instrumenteels: die dryfkrag agter die metafisika van die Idealisme is volgens Adorno juis die onderwerping van die nie-identiese in die objek aan die instrumentele denke of die idee. Hierdie idealistiese trek van die moderne filosofie is terselfdertyd die dryfkrag agter die onderwerping van die natuur, wat Adorno as die 'enjin' van die dialektiek van die Verligting beskou, en wat deur Adorno beskou word as die wesenskenmerk van die geskiedenis: '... Die sisteem is die buikskot wat gees geword het en woede die merkteken van een en elke Idealisme' (Adorno 1973:23 ev). Hierdie merkteken van die Idealisme woed hom uit in die onderwerping van die objek aan die subjek, en van die partikuliere aan die universele.

Wat die postmoderne karakter hiervan dra, is dat Adorno oortuig is dat hierdie werking van die Idealisme ook die subjek ernstig beskadig. Postmoderniteit het dit nie alleen oor die rehabilitering van die objek nie, maar ook oor die beskadigde subjek: ook die Self lei onder sy onderwerping van die Ander. Die subjek verloor alles wat sy subjektiwiteit kenmerk, alles wat spontaan en individueel aan hom is, en word, soos die Idealisme waarvan hy die sogenaamde bevoorregte en 'verligte' produk is, 'n geslotesisteem van wetmatighede wat aan hom voorskryf wat sy identiteit, ervaringe en so meer behels. Adorno sê by implikasie dat die moderne filosofie die skade wat die Idealisme die subjek berokken, ontken en dat hierdie ontkenning of gebrek aan selfinsig tot die selfondermyning van moderniteit lei of sal lei: eenheid is verdeling (kyk ook Adorno 1973:178vv). 
Die terminologie waarmee Adorno hierdie sentrale en verabstraheerde problematiek aandui, het in sy kritiek op die Idealisme, veral op Hegel, 'n beslag gelê. Hegel se filosofie is volgens Adorno gekenmerk deur die pretensie dat dit die wese van die werklikheid as Geist kon begryp. Elke rasionele is reëel en elke reële rasioneel. Teenoor hierdie pretensie van Hegel stel en propageer Adorno die belang van die Ander, met ander woorde dit wat níe deurgegaan het as Geist, reële of rasionele nie. Die moderne filosofie het hom by monde van Hegel versoen met die wêreld, deur dít wat nie in sy rasionele begrippe pas nie, te verontagsaam en alleen maar dit tot werklikheid of Geist te verhef wat wel in daardie begrippe vasgevat word. Die Hegeliaanse geskiedsfilosofie is deur en deur 'n subjekgesentreerde geskiedsfilosofie. Dit is 'n geskiedenis van die subjek en nie (minstens ook) van die nie-subjek nie. Daarom, teenoor die primaat van die subjek in die Idealisme, stel Adorno sy Vorrang des Objekts (Adorno 1973:19, 394).

Adorno se strategie behels om in en met die filosofie dít wat deur die filosofie se begriplike denke buite rekening gelaat word, tegemoet te kom. Die waarheid rondom die objek is juis dat dit in verset teen hierdie onderdrukking die voorrang bo die begripsmatige subjek verkry, in dít wat deur die begripsmatige onderdruk en verag is (Adorno 1973:21, 144). Dit wat die begrip eintlik pretendeer om te bied, sou volgens Adorno eers gerealiseer word wanneer dit die kenobjek tot uitdrukking bring, soos wat dit an sich is, in plaas daarvan om die kenobjek ' $n$ voorbeeld van begriplike algemeenheid te maak. Met ander woorde - in Adorno-taal - om te praat waaroor nie gepraat kan word nie (Adorno 1973:25). Om hierdie taakstelling van oënskynlike teenstrydigheid gestand te doen, moet Adorno 'n soort ontmitologisering voltrek waarin die pretensie van selfgenoegsaamheid en die skynselfstandigheid van die begrip duidelik sou blyk. Dit is 'n negatiewe taakstelling. Die negatiewe taak van hierdie filosofie, soos wat dit deur 'n negatiewe dialektiek geformuleer word, wil egter tot die positiewe lei en dit is wat die Adorniese begrip 'kritiese negasie' (bestimmte Negation) beteken.

In Adorno se negatiewe dialektiek is daar geen plek vir ondoelmatige negasie of, soos by Derrida, vir 'n negasie ván negäie nie. Dit moet iets positiefs oplewer. Daarom neem Adorno Hegel dit kwalik dat hy met sy voortgaande negasie maar net tot die negatiewe teruggekom het en dat sy kritiek maar net 'n apologie (vir die subjek) geword het. Wanneer Adorno die negasie wel negeer, sou dit net wees omdat die voorafgaande negasie nie negatief genoeg was nie (Adorno 1973:162). Die negatiwiteit van Adorno se denke het ook geen geleiers in die een of ander prinsipe nie: daarom verseg ay om sy standpunte te fundeer. Definisies is totaliserend. Die fundering van 'n standpunt is vir Adorno terselfdertyd die ontkragtiging daarvan. Negative Dialektik ontwikkel daarom intern en ook selfrefleksief 'n radikaliserende kritiek, waar Adorno 
steeds met die medium van denke die allesdeurdringende maatskaplike mag kritiseer. Die geladenheid van Adorno se kritiek op die (identiteit)sisteem is dus 'n gevolg van sy identifkasie van die teoretiese sisteem en die totalitêre magsgedronge maatskaplike sisteem. Daarom word die filosofiese sisteem, soos die maatskaplike sisteem, gekritiseer asof dit 'n sistematiese weerspieëling is van dié maatskaplike mag waarin beslis word wie mag voortbestaan en wie vernietig moet word. In die vernietigingsindustrie wat deur verskynsels soos Auschwitz verbeeld word, sien Adorno die kulminasiepunt van 'n denke wat geen respek toon vir dít wat nie opgeneem wil (kan) word in die kategorieë van mag nie. Hierdie vernietigingsindustrie toon vir Adorno die stand van die geskiedenis aan: dat dit hoegenaamd moontlik was dat Auschwitz kon plaasvind, juis te midde van die Westerse tradisie van 'vooruitgang', die hoëre, kuns, filosofie en Verligting, bring Adorno retrospektief tot 'n radikale kritiek in Negative Dialektik. Die totale inhoud van hierdie bedenklike filosofiese tradisie word deur Adorno in sy kritiek van identiteitsdenke vernietigend blootgestel: alle kultuur na Auschwitz, en ook die kritiek daarvan, is vervalle (Adorno 1973:359).

Die logiese konsekwensie van Adorno se kritiek van die sistematiese identiteitsdenke, is dus dat die subjektiewe denke sistematies van sy kennis en uitdrukking van daardie kennis beroof word. Adorno se kritiek van identiteitsdenke het daarom in die oog om die subjek/Self te laat verdwyn, of liewer, op die agtergrond te skuif en na aanvaarbaarder proporsies toe af te bring, ten bate van 'n objek/Ander wat eens geabstraheer (dit is ge-klein-eer) is, maar wat nou deur negatiewe dialektiek 'n stem verkry.

Konkluderend kan aangemerk word dat dit duidelik is dat die Adorniese kritiek van die identiteitsdenke heelwat met postmoderne kritiek te make het. In die eerste plek is dit, tipies van die postmoderne opgaaf, kritiek wat wesenlik met die Ander gemoeid is. Die kritiek van die identiteitsdenke wil juis poog om die nie-begripsmatige, die niekonseptuele werklikheid, die onderskatte en die ongenuanseerde te red: dit wil sê, dit poog om die Ander te beredder. Die kritiek van die identiteitsdenke is duidelik ook kritiek van begripsmatige redelikheid as verengde en verengende redelikheid, en as sodanig ook kritiek van die moderne rede. Dit is ook opvallend 'n kritiek wat die objek, en nie die subjek nie, probeer propageer en wat sterk krities staan teenoor die rasionele en konsepafhanklike subjek. Verder is die kritiek van die identiteitsdenke as 'n implisiete Auseinandersetzung met Hegel en sy nalatenskap, krities teenoor moderniteit.

Die kritiek van die identiteitsdenke sny ook aan by postmoderne kritiek in die sin dat dit intens selfkrities en selfverwysend opereer. Dat hierdie selfkritiek ook vir Adorno se eie filosofie problematies raak, ook metodologies problematies, hoef nie vir sy leser noodwendig problematies te wees nie. Miskien, wanneer 'n mens ook na die 
problematiese rondom Foucault gaan kyk, hóórt postmoderne kritiek intern so onstabiel, ambivalent en problematies te wees? Die saak waaroor dit tog uiteindelik gaan, is dat kritiese introspeksie deel uitmaak van die postmoderne kritiek, en dit is die kritiek van die identiteitsdenke wel. Alhoewel eg-moderne filosowe soos Kant en Lukács om maar twee te noem - introspeksie ook as 'n voorvereiste vir filosofie stel, is daar by hulle nie dieselfde (siniese) gevolgtrekkings as waartoe postmoderniteit gekom het nie. Hulle laat in ieder geval nie soos Adorno hierdie introspeksie toe om hulle eie filosofie uiteindelik te destabiliseer nie. Dit is ook opvallend dat die kritiek van die identiteitsdenke uit 'n skeptiese houding teenoor die moderne samelewing ontspring. Dit is, en so hoort alle postmoderne kritiek te wees, teleurgestelde en siniese kritiek. Eg-moderne filosowe soos Kierkegaard en Marx was ook teleurgesteld in moderniteit, maar hulle vind die opiossing vir die probleem juis weer terug in die subjek, waar postmoderniteit (en die kritiek van die identiteitsdenke as 'n negatiewe kritiek) ter wille van selfhandhawing juis die moderne subjek as voedingsbron van die skepsis teenspreek.

Voorts, en by uitstek, poog die kritiek van die identiteitsdenke om die gefragmenteerde nalatenskap van moderniteit aan te spreek deur te poog om die partikuliere, vroeër verswelg deur die geheel, in die gesigsveld te begin bring.

\section{Das Ganze ist das Unwahre.}

Hierdie Adorniese sisteemkritiek bring die sistematiese teologie miskien tot eietydse/ sisteemkritiese selfinsig. Op die minste konfronteer die postmoderne sisteemkritiek die sistematiese teologie met die vroegste impuls van die Westerse gees: Gnothe seauton? Ken jy (nog) jouself?

\section{Literatuurverwysings}

Adorno, T W 1970. Gesammelte Schriften (GS, 23 Bande.) Frankfurt am Main: Suhrkamp.

1970. Ästhetische Theorie, in Gesammelte Schriften 7.

1971a. Drei Studien zu Hegel, in Gesammelte Schriften 5, 249-380.

1971b. Zur Metakritik der Erkenntnistheorie, in Gesammelte Schriften 5, 9245.

1972. Soziologische Schriften, I, in Gesammelte Schriften 8.

1973. Negative Dialektik, in Gesammelte Schriften 6, 8-412.

1974. Philosophische Terminologie. (2 Bande.) Frankfurt am Main: Suhrkamp.

1977a. Kulturkritik und Gesellschaft, I: Prismen, in Gesammelte Schriften 10.1, 9-287. 
Adorno, T W 1977b. Kulturkritik und Gesellschaft, II, Stichworte, in Gesammelte Schriften, 10.2, 597-782.

[\& Horkheimer, M] 1984, Dialektik der Aufklärung, in Gesammelte Schriften 3.

Beukes, J 1994. Hervormde teologie is 'n filosofiese teologie. Die Hervormer 1 Maart $1994,6 / 6$.

Derrida, J 1978. Writing and difference, translated by A Bass. London: Routledge. Habermas, J 1983a. Die Philosophie als Platzhalter und Interpret, in Moralbewußtsein und kommunikatives Handeln. Frankfurt am Main: Suhrkamp.

- 1983b (Hrsg). Adorno-Konferenz. Frankfurt am Main: Suhrkamp.

1984. The theory of communicative action: Reason and rationalization of society, Volume 1, translated by T McCarthy. Boston: Beacon.

1985. Die neue Unübersichlichkeit. Frankfurt am Main: Suhrkamp.

1987a. The philosophical discourse of modernity, translated by F Lawrence. Cambridge: Polity.

1987b. The theory of communicative action: Lifeworld and system - A critique of functionalist reason, Volume 2, translated by $\mathrm{T}$ McCarthy. Boston: Beacon.

Van Aarde, A 1995. Kerk en teologie op pad na die derde millennium: 'n Paradigmatiese verskuiwing van middelmatige aard. HTS 51/1, 13-38.

Van Wyk, G 1994. In die postmoderne tyd moet die teologie 'n filosofiese teologie wees. Die Hervormer 1 April 1994, bl 6. 